\title{
ANALYSIS OF CONSUMPTION BEHAVIOR RELATED TO LOCAL PRODUCTS AND THEIR ONLINE DISTRIBUTION
}

\author{
Zsolt Ádám Orbán \\ $\mathrm{PhD}$ student \\ Hungarian University of Agriculture and Life Sciences, Doctoral School of Economics and \\ Regional Science \\ E-mail: orban.zs.adam@gmail.com
}

\begin{abstract}
While the literature and the EU's agricultural policy emphasize the role of local products and short supply chains (SSC), the market opportunities for small farmers are increasingly barren due to the price-depressing effect of large multinational firms, which can also be seen in local networks. The main goal of the paper was to examine how the local market as a classic form of the short supply chain can be characterized and whether its operation could be helped by modern solutions. The involved primary research has focused on the opinion of the farmers and costumers about Hungarian and local products in the Kecskemét micro region as a traditionally agricultural area. Using questionnaires and in-depth interview method the shopping habits and preferences of the costumers and the experience of the farmers concerning to local food and SSC were analyzed on the local market of the micro regional center in Kecskemét city. During the research there was a focus on the communication channels and the information flow between the producers and consumers. Based on the results the consumers consciously buy and prefer local agricultural products creating a good economical basis for local farmers. However there is a definite need for better communication and more information in SSC. Modern solutions and marketing channels (e.g. web shops, direct websites, Facebook profiles and other IT solutions) have been identified as key factors.
\end{abstract}

Kulcsszavak: local product, agriculture, competitiveness, short supply chain, marketing channels

JEL besorolás: $Q 19, R 19$

LCC: S539, HD1501

\section{Introduction}

Caused by the price-depressing effect of the large global chains smaller producers and distributors are slowly but gradually being pushed out of the market, their market position is declining more and more. Small farmers have long been in a vulnerable position as purchasers have a significant influence on prices. Local markets are also in a vulnerable position because it is difficult to compete with the marketing activity of large global chains.

The biggest issues of Hungarian agriculture are the low level of cooperation, the untapped potential of rural tourism and the low level added-value production of small agricultural enterprises, causing many times economical and social problems. At the same time the potential of the sector as well as the still living agricultural traditions can be clearly classified as local values (see Ritter, 2014 and 2018). The preservation of these values is a key task for the rural development in Hungary.

The interests of those involved in direct sales - such as producers and end-users - are the same. Therefore - based on the literature - there is a great chance to establish joint marketing channels 
between the actors, and thus it is easier to connect supply and demand (see Péter and Illyés, 2019).

From this point of view the need for a system where the information (such as new product sales, new products or other important marketing data which are currently difficult or impossible to reach by the customers) can flow more easily or even where the products could be purchased has come to the fore side.

\section{Literature review}

According to Lehota and Csíkné (2012) three basic forms can be distinguished between commodity exchange forms:

1. The producer is "not in motion": e.g. during rural tourism activities or open days there is the opportunity to visit rural producers on their own farms and buy products directly there.

2. The customer is "not in motion": producers transport their products with their own vehicles or with mobile devices that allow them to transport and sell their goods safely (most typically meat and bakery products are sold with this method in Hungary - see Juhász and Szabó, 2013).

3. The customer and the producer "meet halfway": for example producer markets, fairs, and other places where both supply and demand side actors move for exchange. According to Benedek et al. (2013) the popularity of producer markets describes an increasing curve, despite the fact that prices in such marketplaces - especially for premium products - are particularly high and that the product range is limited compared to the supermarkets.

According to Juhász (2012) the last form is significant for more conscious consumers. motivated by higher social and environmental orientation - e.g. green thinking, trust-based shopping and patronage of local producers. Local purchases also have a much more complex impact on the local community and economy, which may even include local funds (see e.g. Varga 2016 or 2017). Local production and consumption of local products are key factors of local economy that address the topic of short supply chains and direct sales.

According to an OECD (1995) study or results of Ritter (2008) direct food sales could be a development tool for peripheral rural areas. Using direct sales and short supply chains the unfavorable effects of wholesalers' pricing policies could be avoided, while diverse sources of revenues might stabilize the financial balance of local firms (Benedek, 2014).

According to Kotler and Keller (2006), the members of the sales and advertising channel are autonomous organizations whose purpose and task is to release the produced goods for sale. A model of this sales and advertising channel is shown in Figure 1.

According to Póla (2014) the difference between direct sales and short supply chains can be summarized as follows: In producer markets direct exchange of goods is common, and in all purchases in which the producer sells the product directly to the end user it is called direct sales. If a retailer is included in the process it is already short food chain. So the short food chain does not refer to the availability of the product nearby, it really means the presence of at least one retailer in the process. 


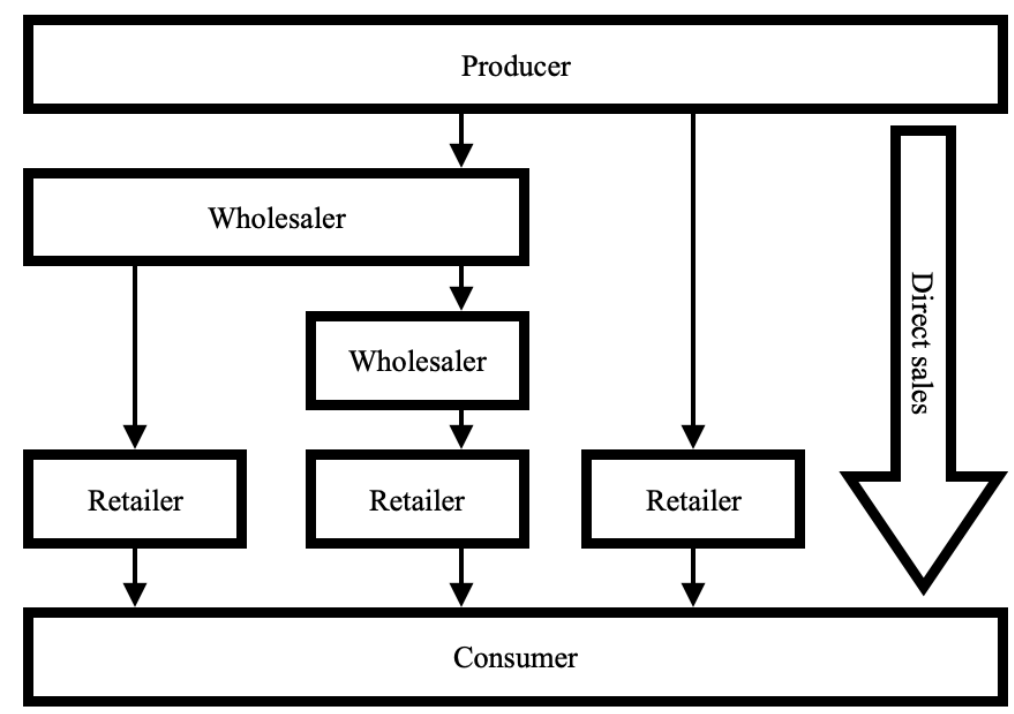

Figure 1: Distribution channels for goods

Source: own edition based on Imreh et. al (2013), 2021

According to the literature (eg Póla 2014; Gorotyák 2013 or Balázs, 2012) direct and short supply chains include the following typical sales methods: farm sales, roadside sales, pick-up promotions, host shops, point-of-sale and delivery, customer circles, consumer associations, internet sales, sales at events and products sold in rural tourism.

Based on Kuslits and Kocsis (2018) customers who want to receive information about the products in SSC can choose from two systems. In the first case the product description (written on it) could help consumers to identify the origin, composition and other important characteristics of the product. Products certified as local, organic or other special origin generally have these kinds of indications (Kuslits - Kocsis, 2019). Usually these certifications are given by an independent actor (Gallastegui, 2002). In the other case the consumer asks directly the producer about the origin or other details and characteristics of the product during the process of direct sales.

\section{Material and method}

Based on the above mentioned the aim and inspiration of the introduced primary research based on questionnaires and in-depth interviews was to examine how consumers obtain information about producers' products and the reality of a system where they can access product information in an alternative - easier and faster, or more reliable - way, and the product themselves. Further goal was to map the customer behavior in the Kecskemét city market (as the micro regional central market for local farmers) as well as the opinions of the local producers regarding the trends and selling opportunities of their goods.

Based on the literature and previous research experience three hypotheses were set up:

1. As a general feature (i.e. not only on the market) consumers participating in the research consciously buy local and Hungarian products.

2. Only a small proportion of the consumers are willing to pay more for a proven local or Hungarian product than for a cheaper product of foreign - or without proven - origin.

3. Consumers and local producers would definitely use a system that makes it easier to access product information and local products themselves. 
The anonymous questionnaire survey was repeatedly conducted in January and February 2020 with random method in the Kecskemét producer market, and a total sample of 410 participants was achieved.

In addition to the questionnaire survey structured in-depth interviews were made with 43 local producers selling on the selected market, using direct sampling technique .

The analyzed market is located in Kecskemét city, the center of Kecskemét micro-region (see Figure 2.). The selected micro-region and the city itself located in the middle part of Hungary in the Great-Plane macro region, which is the most important agricultural area in Hungary (that was the reason for the selection indeed).

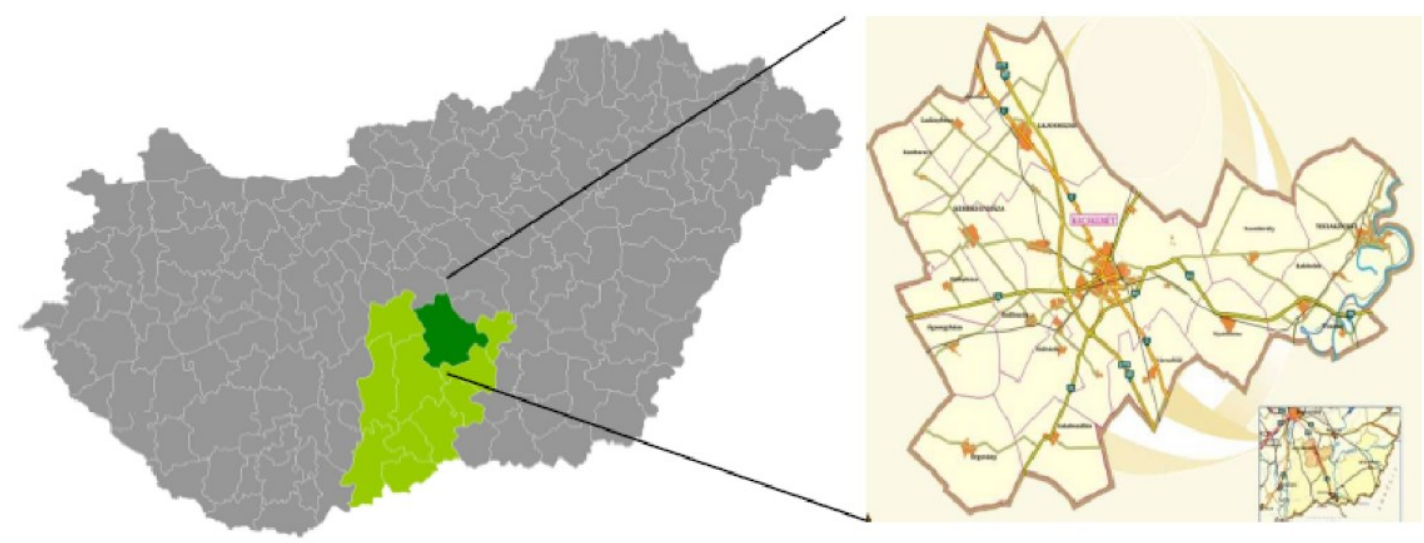

Figure 2: Location of Kecskemét micro-region and city of Kecskemét in Hungary Source: own edition, 2021

The development of the city and the region is traditionally based on animal husbandry, crop production and especially on vegetable and fruit production from the middle of the 19th century. The level of development is closely related to the central trading function due to the city's excellent geographical location. In the economic structure of Kecskemét, the agricultural and agricultural-related processing (canning) industry and the trade have always played an important role. The central market in Kecskemét - where the questionnaire was made nowadays also serve as a place for selling local food produced by small farmers within 30-40 kilometres range and for buying fresh goods by the locals.

\section{Results and discussion}

The questionnaire included traditional questions (such as gender, age, education, and occupation) and the following topics: shopping habits, consumer preferences, price sensitivity, market evaluation, own (home) production concentrating on local products, their sales and the relevant information system. This paper focuses only on the most important research results.

The age composition of the respondents is shown in Figure 3. Nearly $80 \%$ of them are between 25 and 65 years old. Unsurprisingly, those under 25 make up less than $5 \%$ of all respondents, as this age group is not yet "market preferring" according to local vendors. 


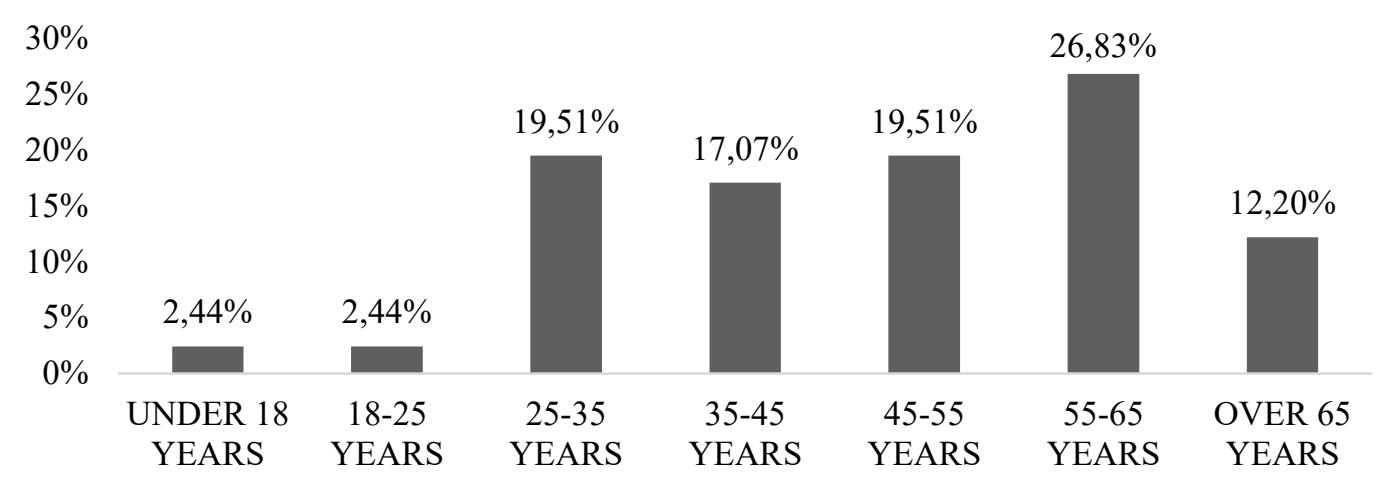

Figure 3: Distribution of respondents by age group (\%)

Source: Own research and editing, 2021

It can also be observed that the 25-35 age group is presented with a high share of almost $20 \%$. This age group is already consciously entering the market in order to buy quality and probably local product. However it can also be observed that the market is still the most attractive shopping option for older age groups, as evidenced by the fact that almost $38 \%$ of the respondents are in the age over 55.

The respondents can be divided into two major groups examining their education (Figure 4). $44 \%$ of respondents have a college or university and $42 \%$ have a secondary school or grammar school degree. The proportion of primary school degree was $7 \%$, similar to those with a vocational education.

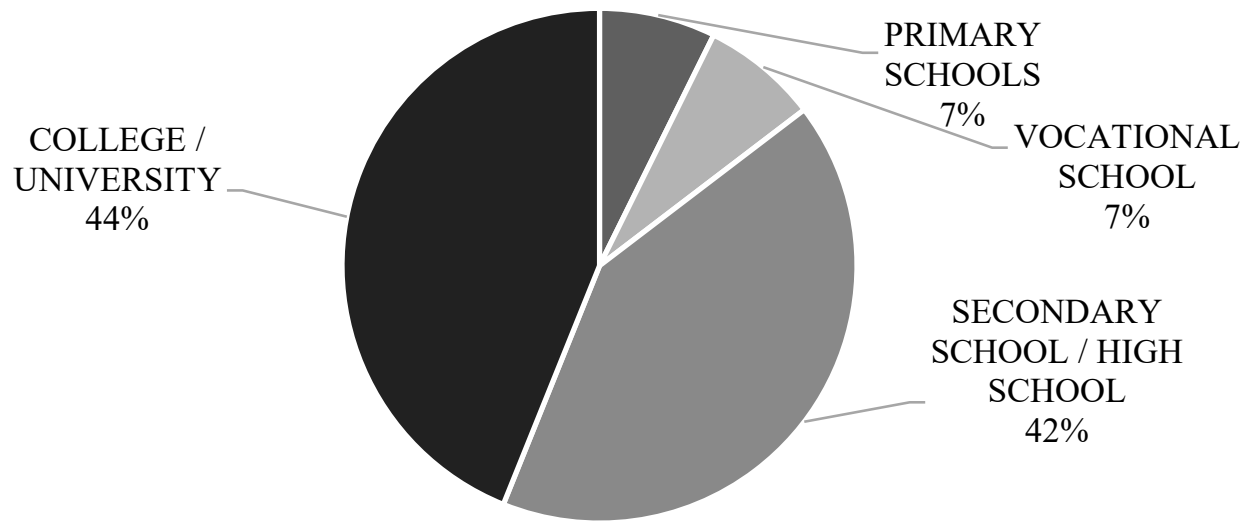

Figure 4: Distribution of questionnaire respondents by education (\%)

Source: Own research and editing, 2021

As for profession (Figure 5) the leaders with intellectual profession present only $2.4 \%$ of the total sample. Students, the unemployed and middle managers in manual occupation present a total of nearly $15 \%$ (all three groups with $5 \%$ ), while both middle managers and primary producers with intellectual professions are represented by almost 7\%. Retirees accounted for $12 \%$ and intellectuals for subordinates by $17 \%$. The largest professional group who filled the questionnaires was the group of businesspersons with a total share of $22 \%$. 


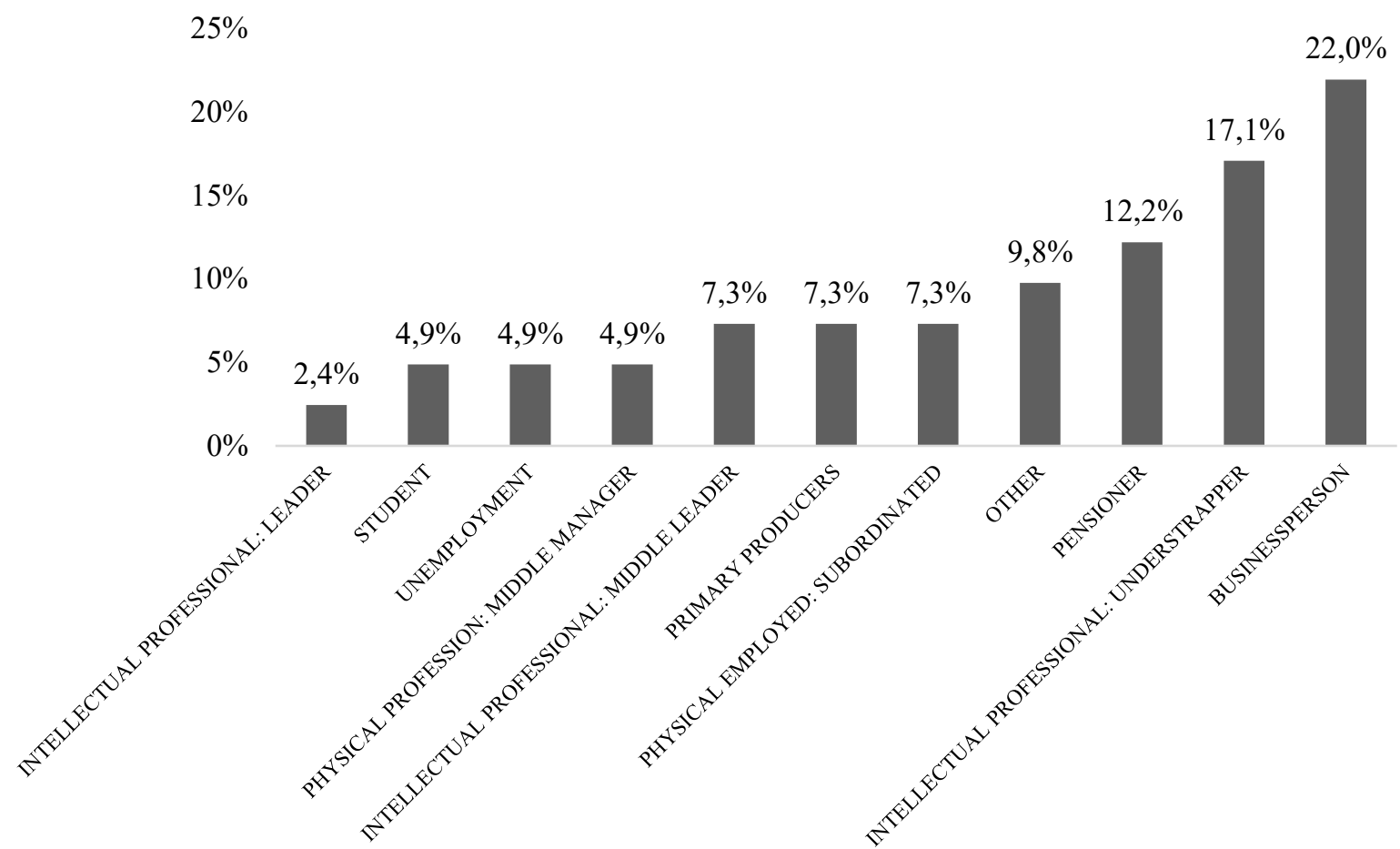

Figure 5: Distribution of questionnaire respondents by profession (\%)

Source: Own research and editing, 2021

It was investigated whether the respondents consciously buy Hungarian products (see Figure 6). Only $2.4 \%$ of the respondents do not consider it important to buy directly Hungarian products. The rate of those who do not pay attention to what product (Hungarian or foreign) they buy is $19.5 \%$. $78 \%$ of the total indicated that they consciously buy directly Hungarian products, although this high amount is might be influenced by the location of the research.

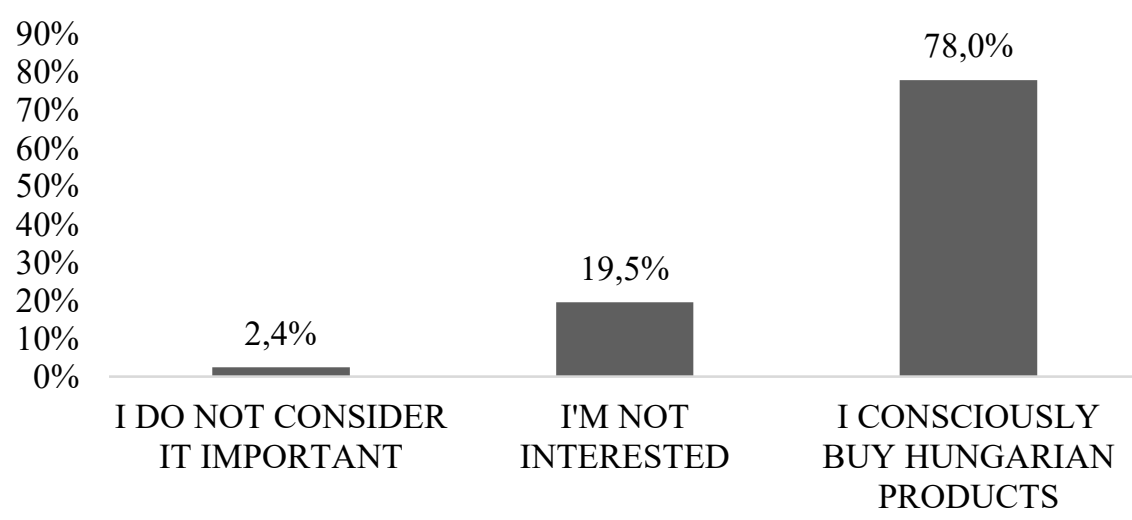

Figure 6: Distribution of respondents to the questionnaire according to the assessment of conscious Hungarian product purchase (\%)

Source: Own research and editing, 2021

One of the most significant bases of the spread and wider purchase of local and Hungarian products is the price. According to local producers and small shop owners operating on the Kecskemét market, Hungarian customers are still price sensitive. This was also proved by Nagy (2019) in a representative research. Based on the results of his online questionnaire research it 
can be stated that for every fifth customer product pricing is the most important variable. Ergo a significant proportion of buyers follow price-sensitive or price-conscious buying habits.

It was also examined what percentage of the respondents would be willing to pay more for local and Hungarian products with a reliable origin (Figure 7). Based on the results, those who would pay between $5 \%$ and $15 \%$ more for that kind of products are almost $80 \%$ of the respondents. Within the total sample $36 \%$ of the respondents would be willing to buy at least $5 \%$ and at most $10 \%$ more expensive. The proportion of those who would pay $20 \%$ or more was close to $18 \%$. In contrast with the literature on price sensitivity and the opinion of the asked local producers only $2.6 \%$ of the sample would certainly not pay more in this case.

According to local farmers it is often not only the price that makes it difficult to sell their products but also the lack of sharing information, promotions and other marketing materials. Moreover this is usually a bigger problem than the higher average price compared to supermarkets according to the interviews.

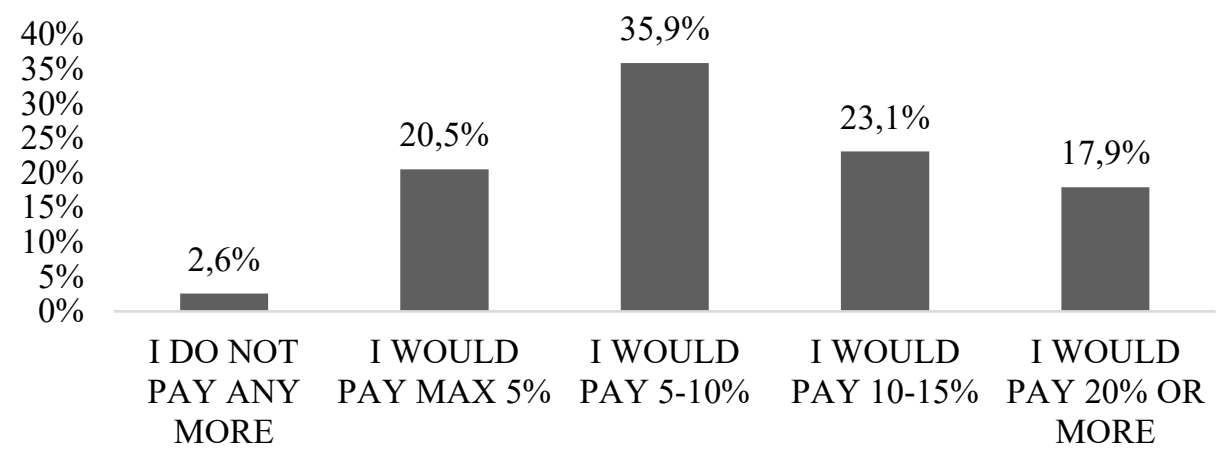

Figure 7: Distribution of respondents according to the degree of willingness to pay extra for guaranteed local/Hungarian products $(\%)$

Source: Own research and editing, 2021

In this regard research participants identified friends with a share of nearly $60 \%$ (Figure 8 ) as the primary source of information about producers' actions and information. The second highest value was achieved by the Internet (almost 24\%) thanks to the Kecskemét market's own website, which is sufficiently updated and has a lot of information for those interested.

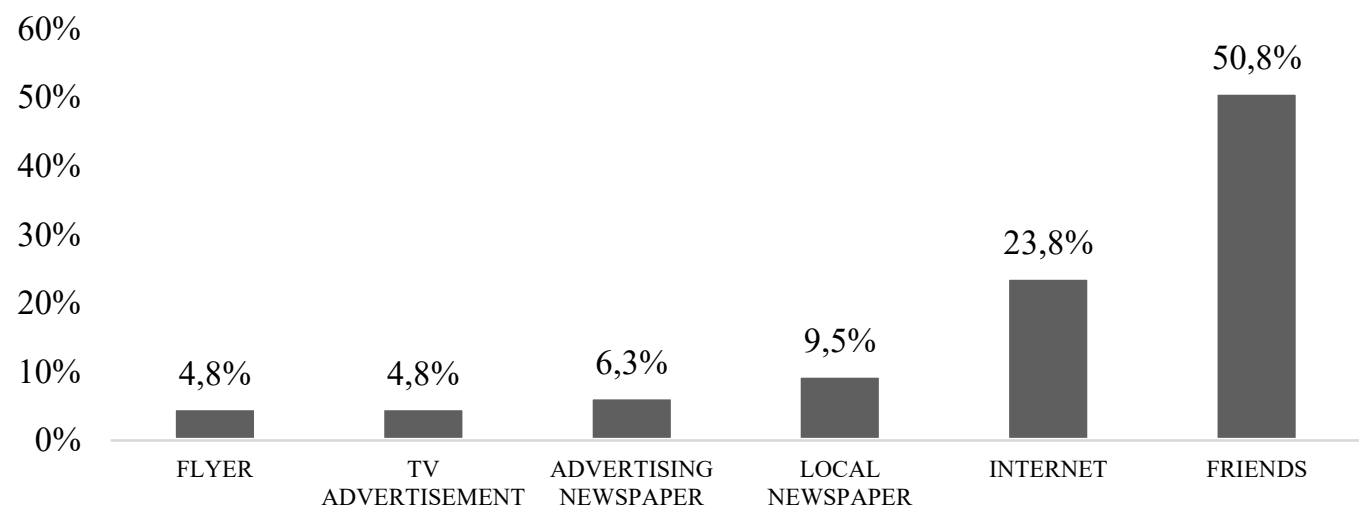

Figure 8: Distribution of respondents based on how they receive information about local products (\%)

Source: Own research and editing, 2021 
On Google Maps website the Kecskemét market reviews category has more than 1,500 reviews. This is very important for the millennial generation, as this generation checks everything on Google (or other websites), where the assessment of such markets could also be checked.

The customers were asked if they would be interested in a system that would make it easier to find information directly about local products / producers / promotions. Based on the results (Figure 9.) $56 \%$ of respondents would be willing to use such system. Nearly $20 \%$ of those who found the idea interesting and would probably try it. The proportion of those who might try it was $17 \%$, and only $7.3 \%$ were those who do not even want to try it.

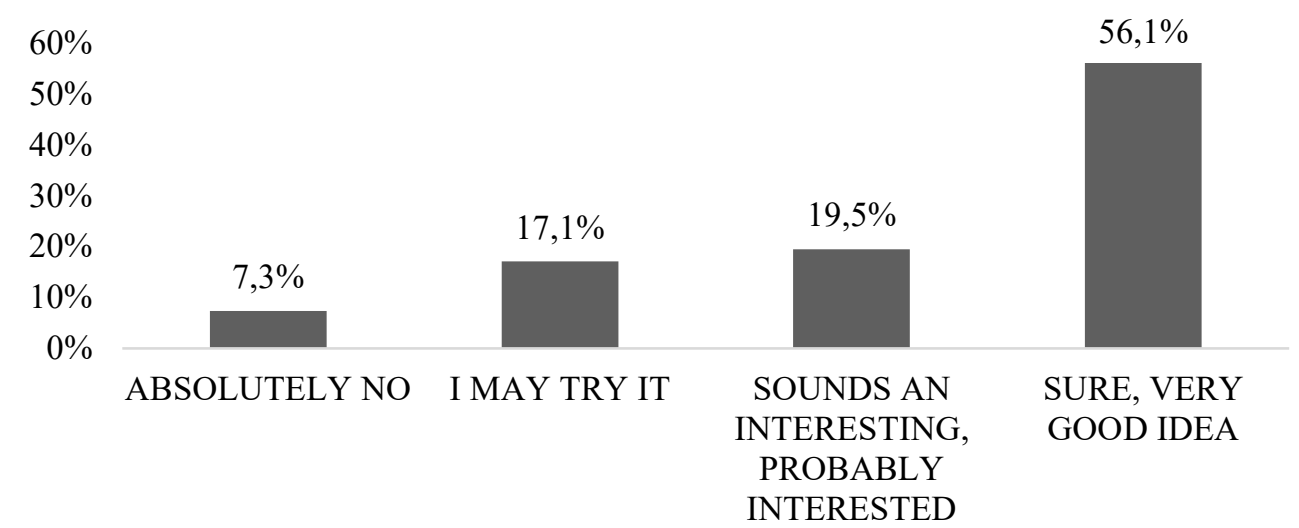

Figure 9: Distribution of respondents based on their willingness to use a new product information system (\%)

Source: Own research and editing, 2021

Finally the intention to buy from a system providing direct and reliable information about producers and their products was examined (Figure 10.). In this case $34 \%$ of respondents would be willing to buy from this system and find it a very good idea. Nearly $27 \%$ of respondents find it interesting and would probably buy from such an opportunity. $24 \%$ might try it out and it was $14 \%$ of those who wouldn't try it in any way. Taking the fact that $40 \%$ of those surveyed are over 55 into consideration, the results can be evaluated quite positive, as older generation generally tend to be less inclined to innovation and "new" things.

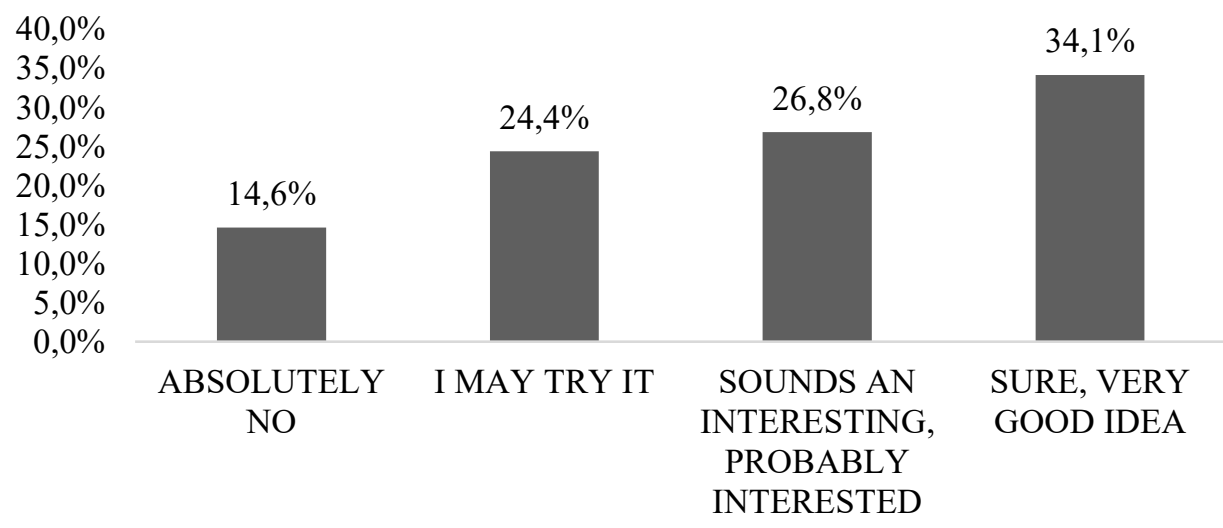

Figure 10: Distribution of respondents based on their willingness to buy from an online system (\%)

Source: Own research and editing, 2021 
The results of the questionnaire can be amended by the qualitative results of the structured indepth interviews with local producers. These interviews were conducted along the following topics:

- Experience with products sold in the market;

- Competition with the big traders;

- Motivations of their customers;

- Cooperation between producers;

- Stability of the demand;

- EU and national regulations;

- Communication channels and public relations.

The producers/farmers included in the research are characterized by the following activities: animal husbandry, horticulture, pomiculture and selling row material or processed food (e.g. pickles, jams, milk products etc.).

Producers have good selling experience on the market in general. They don't have to explain much about their own products, customers look for their products directly. The environmental conditions of the farmlands, the excellent (bio)quality of the product, the better taste and content were identified as competitive advantages compared to other similar products sold by supermarkets.

As for competition local producers "fight" with the concurrency on the producer market and with multinational corporations/supermarkets as well. There are lots of vendors selling not their own but from the wholesale market bought products on the market. Based on the producers' comment it would be necessary for primary producers to be allocated in a separated part of the market, and new regulation is needed.

Regarding wholesale chains, producers are of the opinion that competition cannot be interpreted in same dimension: a) the products are not similar, and b) wholesalers have serious marketing budgets and use different marketing channels and mass media opportunities. Therefore it is very hard to compete for the same niche.

In terms of consumer motivation almost all the producers commented that the reliability of the products and their constant presence in the market means guarantee that customers would buy from them. Many of them have certain customers that has been spreading for generations, which means a solid base.

There was only one producer who had some form of cooperation during the research period. According to most farmers there is no cooperation, which makes it difficult to really almost everything. There is no actor who brings farmers together.

There would be a need for a specialist who would bring them together and represent their interests. Based on the interviews young producers should be gathered first. Establishment of small collaborations at settlement level, meetings in certain forums, and establishment of common product names should be encouraged, which. Producers should not see each other as competitor but rather as a partner.

In terms of competitive advantages quality, authenticity and personal contact (which is even the best advertising method) came to the fore. Disadvantages included prices controlled by 
traders and not by producers, the difference in volume compared to wholesalers and the lack of marketing activity.

The asked producers have identified a stable customer base of between $45 \%$ and $95 \%$ of their customers in relation to their activities. In case of all producers it can be stated that they have a stable customer base and they do not fear that it will decrease in the future.

As the Chamber of Agriculture still has nothing to do with the concept of family farms, primary producers and family primary producers, in terms of regulation the Chamber of Agriculture should first be operated better to follow the producers' needs and then these needs should be interpreted towards the government and the EU. The government and the EU should distinguish the producer from the trader in regulation policy, that is the main key.

The idea of a new system that would make it easier to get information about local products / producers / promotions and where the product could be bought from was considered a good idea by every interviewed producer. The need for innovative solutions, new marketing channels and better communication with the customers are also identified reasons for that. As people become more comfortable any new feature that could make shopping more convenient (in this case, among local products) fits to the new needs on the market and could be useful for both buyers and producers.

\section{Conclusions}

At the beginning of the research three hypotheses were set up. The first one supposed that the consumers participating in the research consciously buy local/Hungarian products as a general feature (i.e. not only on the market). This hypothesis has been verified as almost $80 \%$ of the respondents indicated conscious buying of those products. People involved pay a lot of attention to where they buy products from. In case of a subsequent research, it would worth examining a place where products of both foreign and local origin can be found and comparing the results with data from current research.

Second hypothesis supposed that the consumers in the research are only willing to pay a small amount more for a reliable local product. This hypothesis couldn't be verified as more than $97 \%$ of the respondents would be willing to pay more for those products. If more accurate data are to be obtained, a more precise methodological, comparative study should be conducted. This is definitely an important direction for continuing research.

The last hypothesis supposed that research subjects would use a system through which they could more easily access information and buy local products. It was verified, as nearly $93 \%$ of respondents declared they would use this system in some form, and $86 \%$ of respondents showed some positive willingness according to the possibility to buy products via this system.

During the deep interviews, it became clear that there are many opportunities for producers to take advantage of, but this is not easy. Regarding modern options / tools, the producers mentioned the problems caused by the lack of modern communication and marketing channels e.g. webshop / website and Facebook profiles. It is strongly suggested to move in this direction, as it is already important to grab these opportunities. Facebook as a marketing channel and IT techniques could be great for providing the producer, followers, and acquaintances with local promotions, newer products, publishing locations, or other useful information. 
However it is not an easy task. The operation of a webshop or a Facebook profile must be under constant supervision, which means that either the producer himself or an employee or a company engaged in such a job has to take care of it. This can be too burdensome for a producer, both financially and in terms of time, especially in older age.

Based on the results the main motivations of the customers for buying local products are the reliability of the products, the exact knowledge of their place of origin, and the outstanding quality.

The question whether they would be willing to use a system where information, promotions, and other marketing data related to the products available for purchase, was answered in the affirmative. The research experience was a positive attitude from producers on the same topic as well.

Asking whether they would be willing to buy through this system, a high proportion of respondents indicated willingness. Similar opinions were expressed by producers, as they could alleviate growing competitive disadvantages and provide a means of diversification and revenue opportunities.

Overall a number of new issues have emerged during the preparation of the research. Further research is needed in locations (and surfaces) where not only local products can be purchased, and where it is more representative and more generally possible to assess whether consumers are actually willing to pay more for a local/Hungarian product than for a foreign product. It is also necessary to ask even more producers what could be done to improve their current situation.

\section{References}

1. Balázs, B. (2012): Local food network development in Hungary. International Journal of Sociology of Agriculture and Food 19 (3) 403-421. p.

2. Balázs, B. - Simonyi, B. (2009): Együtt a helyi élelmiszer rendszerekért (Together for local food systems) - Civil összefogás a kistermelői rendelet módosítására. Védegylet, ESSRG, Budapest.

3. Benedek Zs. (2014): A rövid ellátási láncok hatásai (Impacts of short supply chains.). MTA Közgazdaság- és Regionális Tudományi Kutatóközpont, Budapest

4. Benedek Zs. - Fertő I. - Baráth L. - Tóth J. (2013): Hogyan kapcsolódhatnak a mezőgazdasági termelők a modern élelmiszerláncokhoz? (How can farmers connect to modern food chains?) A rövid ellátási láncok müködésének hazai sajátosságai: egy empirikus vizsgálat tapasztalatai. Vidékkutatás 2012-2013, NAKVI, Budapest

5. Gallastegui G. I. (2002): The Use of Eco-Labels: A Review of the Literature. European Environment 12 (6) 316-31. p.

6. Gorotyák I. (2013): Rövid élelmiszerellátási láncok és vidékfejlesztés (Short food supply chains and rural development). Szakdolgozat. EJF, Szeged

7. Imreh Sz. - Deák I. - Kosztopulosz A. - Kürtösi Zs. - Lukovics M. - Prónay Sz. (2013): Gazdasági alapismeretek I. (Basic of economics I.), online oktatási csomag, https://u-szeged.hu/tamop412e-0011-belso/digitalizalt-tananyagok/digitalizalttananyagok?folderID=26601\&objectParentFolderId=26601 Letöltve: 2020.02.18.

8. Juhász A. (Edit.) (2012): A közvetlen értékesítés szerepe és lehetőségei a hazai élelmiszerek piacra jutásában (The role and opportunities of direct sales in the market access of domestic foods) - Élet a modern kiskereskedelmi csatornákon kívül? Agrárgazdaságtani Kutató Intézet, Budapest. 
9. Juhász A. - Szabó D. (2013): Piacok jellemzői fogyasztói és termelői szemmel (Characteristics of markets from the perspective of consumers and producers). Agrárgazdaságtani Kutató Intézet, Budapest

10. Kotler P. - Keller K. L. (2006): Marketingmenedzsment (Marketing Management). Budapest: Akadémiai Kiadó, 921. p.

11. Kuslits B. - Kocsis T. (2018): Körforgás, visszacsatolás a fenntartható élelmiszerpiacon (Circulation, feedback in the sustainable food market). Lépések 23 (2) 6-7.p.

12. Kuslits B. - Kocsis T. (2019): Visszatérés a piachoz: fenntartható élelmiszer fogyasztás Budapesten (Return to the market: sustainable food consumption in Budapest). Magyar Tudomány 180 (6) 884-893. p.

13. Lehota J. - Csíkné M. É. (2012): Értékesítési sajátosságok - közvetlen értékesítési csatornái (Sales Features - Direct Sales Channels). 117-155. p. In: Szakály Z. (Edit.): Agrártermékek közvetlen értékesítési marketingje (Direct sales marketing of agricultural products). Magyar Agrárkamara, Budapest, 251. p.

14. Nagy Sz. (2019): Az ár, a minőség, a márkanév és a környezetbarátság fontossága a vásárlói döntések során (The importance of price, quality, brand and environmental friendliness in customer decisions). 252-264. p. In: „Mérleg és kihívások” - XI. International Scientific Conference. (11.)(2019)(Miskolc-Lilafüred). University of Miskolc, Faculty of Economics, Miskolc

15. OECD (1995): Niche Markets as a Rural Development Strategy. OECD, Paris

16. Péter E. - Illyés L. (2019): A helyi értékesítés szerepe Csíkszereda és vonzáskörzetében (The role of local sales in Miercurea Ciuc and its agglomeration). Gazdálkodás, 63 (3) 204-217. p.

17. Póla P. (2014): Rövid Élelmiszer láncokkal a vidék fejlesztéséért (Short Food Chains for Rural Development). http://www.mvh-hacs.hu/tanulmanyok Letöltve: 2020.02.18.

18. Ritter K. (2008): A helyi fejlesztés esélyei - agrárfoglalkoztatási válság és területi egyenlőtlenségek Magyarországon (Possibilities of local development - agricultural unemployment and territorial disparities). Területi Statisztika 48. (5) pp. 554-572.

19. Ritter K. (2014): Possibilities of local economic development (LED) in lagging rural areas. Acta Carolus Robertus 4 (1) pp. 101-108.

20. Ritter K. (2018): Special features and problems of rural society in Hungary. Studia Mundi - Economica 5. (1) pp. 98-112. doi: 10.18531/Studia.Mundi.2018.05.01.98-112

21. Varga J. (2016): A helyi pénzek megjelenése és szerepe a gazdaságban (The appearance and role of local money in the economy). 161-207. p. In: Kerekes S. (Edit.): Pénzügyekröl másképpen: Fenntarthatóság és közösségi pénzügyek. Budapest: CompLex Wolters Kluwer, 303. p.

22. Varga J. (2017): A Chiemgauer, mint sikeres helyi pénz müködése (Chiemgauer as a successful local money). Közép-Európai Közlemények 10 (2) 91-100. p. 